\title{
SPAM1 wt Allele
}

National Cancer Institute

\section{Source}

National Cancer Institute. SPAM1 wt Allele. NCI Thesaurus. Code C51228.

Human SPAM1 wild-type allele is located in the vicinity of $7 q 31.3$ and is approximately 46

$\mathrm{kb}$ in length. This allele, which encodes hyaluronidase $\mathrm{PH}-20$ protein, plays a role in

hyaluronic acid induced cell signal transduction, and sperm-zona pellucida adhesion. 